\title{
PENERAPAN ANJURAN DIET DASH DIBANDINGKAN DIET RENDAH GARAM BERDASARKAN KONSELING GIZI TERHADAP PENURUNAN TEKANAN DARAH PADA PASIEN HIPERTENSI DI PUSKESMAS LARANGAN UTARA
}

\author{
The Comparison of Dash Diet and Low Sodium Diet based on Nutrition Counseling in Reducing Blood \\ Pressure among Hypertension Patients in Primary Health Center Larangan Utara
}

\author{
Agustina Pungki Astuti' ${ }^{1}$, Didit Damayanti' ${ }^{1}$, Iskari Ngadiarti ${ }^{1}$ \\ 1Jurusan Gizi, Politeknik Kesehatan Kementerian Kesehatan Jakarta II \\ E-mail: agustinapungki11@gmail.com
}

\section{ABSTRACT}

The low sodium and Diet Approaches to Stop Hypertension (DASH) are diets for reducing high blood pressure. This study aimed to analyze the effect of nutrition counseling on the DASH diet compared to low sodium diet on blood pressure in hypertensive patients. The study design was an experimental study that randomly allocated 34 respondents to DASH diet and 35 respondents to low sodium diet. The ages of respondents were 43 to 76 years and women were 74.3 percent. Nutrition counseling was conducted by researchers to respondents who visited health center or Posbindu Larangan Utara. Nutritional counseling was conducted for an average of 20 minutes using existing brochures. Low sodium diet emphasizes reducing sodium intake while DASH diet emphasis more on consuming lots of vegetables, fruit, nuts and low-fat products. Variables collected were the characteristics of respondent, disease, drugs taken and nutritional status, while blood pressure using a sphygmomanometer, food intake including sodium were measured before and 2 weeks after nutritional counseling. Results showed that there was a significant difference in diastolic blood pressure after patients were given DASH diet compared to low sodium diet (p $<0.05)$ and there was a significant difference in delta of systolic and diastolic reduction in DASH diet compared to low sodium diet. Test also showed a significant reduction in systolic, diastolic blood pressure and sodium intake $(p<0.001)$ in both diet groups after receiving counseling. It concluded that DASH diet can be recommended to decrease blood pressure in hypertensive patients with consider nutritional status.

Keywords: hypertension, blood pressure, low sodium diet, DASH diet

\section{ABSTRAK}

Diet Rendah Garam (RG) dan Diet Approaches to Stop Hypertension (DASH) adalah diet untuk menurunkan tekanan darah tinggi. Penelitian ini bertujuan untuk menganalisa pengaruh konseling gizi diet DASH dibandingkan diet RG terhadap tekanan darah pasien hipertensi. Rancangan penelitian adalah eksperimen yang secara acak mengalokasi diet DASH kepada 34 orang dan diet RG kepada 35 orang responden. Usia responden antara 43 hingga 76 tahun dan sebagian besar perempuan $(74,3 \%)$. Konseling gizi dilakukan oleh tim peneliti kepada pasien hipertensi yang memeriksakan diri ke puskesmas atau posbindu Larangan Utara. Konseling gizi dilakukan rata-rata 20 menit menggunakan brosur yang sudah ada. Diet RG menekankan pengurangan asupan natrium sedangkan diet DASH lebih menekankan ke banyak konsumsi sayur, buah, kacang-kacangan dan produk rendah lemak. Variabel yang dikumpulkan adalah karakteristik responden, penyakit dan obat yang diminum serta status gizi sedangkan tekanan darah menggunakan sfigmomanometer, asupan makanan, zat gizi termasuk natrium diukur sebelum dan 2 minggu setelah konseling gizi dilakukan. Hasil menunjukkan adanya perbedaan yang bermakna pada tekanan darah diastolik setelah pasien diberi diet DASH dibandingkan dengan pasien yang diberi diet RG $(p<0,05)$ dan terdapat perbedaan delta penurunan sistolik dan diastolik bermakna pada diet DASH dibanding diet RG. Analisa juga menunjukkan adanya penurunan tekanan darah sistolik, diastolik dan asupan natrium yang bermakna $(p<0.001)$ pada kedua kelompok diet setelah mendapat konseling diet DASH dan diet RG. Disimpulkan diet DASH dapat direkomendasikan untuk membantu menurunkan tekanan darah pada pasien hipertensi dengan memperhatikan status gizi.

Kata kunci: hipertensi, tekanan darah, diet rendah garam, diet DASH 


\section{PENDAHULUAN}

$\mathrm{H}$ ipertensi atau tekanan darah tinggi adalah peningkatan tekanan darah sistolik lebih dari $140 \mathrm{mmHg}$ dan tekanan darah diastolik lebih dari $90 \mathrm{mmHg}$ pada dua kali pengukuran dengan selang waktu lima menit dalam keadaan cukup istirahat/tenang. Peningkatan tekanan darah yang berlangsung dalam jangka waktu lama (persisten) dapat menimbulkan kerusakan pada ginjal (gagal ginjal), jantung (penyakit jantung koroner) dan otak (menyebabkan strok) bila tidak dideteksi secara dini dan mendapat pengobatan yang memadai. $^{1}$

Penyakit hipertensi merupakan the silent killer disease karena orang tidak mengetahui dirinya terkena hipertensi sebelum memeriksakan tekanan darahnya. Hipertensi merupakan penyebab terbesar dari kejadian strok. Menurut Depkes 2019 jumlah penderita strok pada usia 15-59 tahun di Indonesia berada di urutan kelima terbanyak di Asia. Jumlah penderita strok mencapai 8,3 per 100 populasi di Indonesia dengan populasi sekitar 211 jiwa. ${ }^{2}$ Sedangkan berdasarkan Riskesdas 2018, prevalensi penyakit jantung 1,5 persen dan prevalensi penyakit gagal ginjal kronis meningkat dari 0,2 persen (2013) menjadi 0,38 persen (2018). Lebih lanjut kelompok umur 4554 tahun merupakan penderita hipertensi terbanyak $(24,0 \%)$ dibandingkan kelompok umur lainnya, sedangkan berdasarkan jenis kelamin, perempuan $(54,3 \%)$ lebih banyak dibandingkan laki laki (45,7\%). Prevalensi hipertensi di ibukota DKI Jakarta adalah 34,4 persen. ${ }^{3}$

Faktor risiko hipertensi dapat digolongkan atas umur, jenis kelamin, riwayat keluarga, genetik (faktor resiko yang tidak dapat diubah/dikontrol), kebiasaan merokok, konsumsi garam, konsumsi lemak jenuh, penggunaan jelantah, kebiasaan konsumsi minum-minuman beralkohol, obesitas, kurang aktifitas fisik, stress, penggunaan estrogen. Dari faktor resiko hipertensi, sebagian besar disumbangkan dari faktor makanan atau dampak dari perilaku salah terhadap makanan. Maka, selain pemberian obat-obatan anti hipertensi perlu diberikan terapi dietetik dan perubahan gaya hidup. ${ }^{4}$

Terapi diet yang diberikan adalah diet rendah garam (RG) dengan tujuan menurunkan tekanan darah menuju normal.
Penatalaksanaan diet RG juga ditujukan untuk menurunkan faktor risiko lain seperti berat badan yang berlebih, tingginya kadar lemak kolesterol dan asam urat dalam darah. Selain itu, perlu diperhatikan pula penyakit degeneratif lain yang menyertai darah tinggi seperti jantung, ginjal dan diabetes mellitus. Prinsip diet untuk penderita hipertensi adalah makanan beraneka ragam, jenis dan komposisi makanan memenuhi gizi seimbang dan disesuaikan dengan kondisi penderita serta jumlah garam dibatasi sesuai dengan tingkat hipertensi dengan jenis makanan yang terdapat dalam daftar diet. Garam yang dimaksud disini adalah garam natrium yang terdapat dalam hampir semua bahan makanan yang terutama berasal dari hewan, makanan olahan dan bumbu. Garam dapur merupakan salah satu sumber utama garam natrium. Oleh karena itu, konsumsi garam dapur dan makanan yang mengandung natrium perlu dibatasi. ${ }^{5,6}$

Belakangan ini, muncul diet untuk penyakit hipertensi selain diet RG yang disebut Diet DASH (Dietary Approaches to Stop Hypertension). Tidak seperti diet populer untuk menurunkan BB yang belum banyak diuji secara klinis diet DASH yang bertujuan untuk mengurangi tekanan darah tinggi telah lebih banyak diteliti. ${ }^{7}$ Diet DASH adalah pola makan yang kaya buah-buahan, sayuran, biji-bijian, kacang-kacangan, ikan, dan susu rendah lemak. Makanan ini memiliki tinggi zat gizi penting, seperti kalium, magnesium, kalsium, serat, dan protein. Diet DASH dapat menurunkan tekanan darah karena akan mengurangi garam dan gula dalam diet ini. Diet DASH juga menghindari minuman manis, lemak, daging merah, dan daging olahan. 8,9

Yang membedakan antara diet DASH dengan diet Rendah garam ialah diet DASH mengutamakan konsumsi banyak sayur, buah, dan makanan atau produk rendah lemak serta mengurangi konsumsi makanan atau produk lemak jenuh. Sedangkan, diet RG hanya mengurangi konsumsi garam (natrium) dengan tidak lebih dari $100 \mathrm{mmol}$ sehari atau setara dengan $2,4 \mathrm{~g}$ natrium atau $6 \mathrm{gram}$ garam dapur. ${ }^{9}$ Beberapa penelitian menunjukkan hasil yang bervariasi tentang penerapan diet DASH terhadap penurunan tekanan darah pasien hipertensi. Pada penelitian Dewifianita R (2017) menunjukkan bahwa terdapat perbedaan tekanan diastolik sebelum dan sesudah 
diberikan konseling diet DASH dengan nilai $p=$ $0,0104 \quad(p<0,05)$ dan menunjukkan ada pengaruh pemberian konseling diet DASH terhadap perubahan tekanan darah. ${ }^{10}$ Sejalan dengan penelitian tersebut, penelitian Uliatiningsih (2019) menunjukkan ada perubahan yang signifikan antara tekanan darah sistolik dan diastolik sebelum dan setelah intervensi $(p=0,000) \cdot{ }^{11}$

Berbeda dengan kedua penelitian tersebut, penelitian Nadya Syafa (2014) menunjukkan bahwa tidak ada perbedaan tekanan darah sistolik dan diastolik sebelum dan setelah intervensi selama 14 hari. Berdasarkan latar belakang tersebut maka penelitian ini dilakukan dengan tujuan untuk menganalisa penerapan diet DASH dibandingkan diet RG berdasarkan konseling gizi terhadap tekanan darah pasien hipertensi. ${ }^{12}$

\section{METODE PENELITIAN}

Penelitian ini dilakukan di Puskesmas Larangan Utara dan posbindu di wilayah Larangan, pada bulan Februari sampai dengan Mei 2017. Tempat penelitian dipadukan antara kunjungan poli dan posbindu karena adanya keterbatasan pengunjung pada poli gizi puskesmas Larangan Utara. Persetujuan etik penelitian kesehatan untuk penelitian ini diperoleh dari Poltekkes Kemenkes Jakarta II dengan nomor LB.02.01/KE/31/023/2017 tanggal 31 Januari 2017.

Desain penelitian ini dilakukan dengan pendekatan studi eksperimental dimana memberikan intervensi berbeda pada dua kelompok sampel. Dalam rancangan ini dilakukan random alokasi intervensi, kemudian dilakukan pengecekan tekanan darah, asupan natrium dan sayur buah pada kedua kelompok tersebut dan diikuti intervensi konseling pada kedua kelompok. Setelah 2 minggu dilakukan pengukuran kembali pada kedua kelompok. ${ }^{13}$

Populasi dalam penelitian ini adalah kelompok penderita hipertensi di wilayah Puskesmas termasuk Posbindu Larangan Utara sejumlah 2.365 orang. ${ }^{14}$ Berdasarkan aplikasi G Power 3.1 jumlah sampel adalah 64 orang dengan power 80 persen dan alfa 0.05. Sampel adalah penderita hipertensi baik laki-laki maupun perempuan berusia minimal 40 tahun yang berobat ke poli gizi Puskesmas dan Posbindu Larangan Utara. Sampel diambil dengan cara random dimulai dari poli gizi kemudian posbindu yaitu pasien pertama konseling gizi diberi diet RG, pasien kedua diberi diet DASH, pasien ketiga diberi diet RG dan seterusnya. Pada poli gizi Puskesmas Larangan Utara diperoleh 36 responden, sedangkan 33 responden lainnya diperoleh dari Posbindu Larangan Utara. Kriteria inklusi penelitian ini yaitu: responden memiliki penyakit hipertensi, responden sedang memeriksakan diri ke Puskesmas Larangan Utara, responden mengonsumsi obat antihipertensi yang sama selama penelitian berlangsung berupa captopril, responden bersedia mengikuti penelitian.

Intervensi konseling gizi kepada respoden diberikan oleh tim peneliti selama sekitar 20 menit untuk setiap responden di poli gizi atau posbindu saat responden berkunjung. Langkah konseling gizi diawali dengan menyampaikan maksud dan tujuan serta penjelasan sebelum penelitian (inform consent) dilanjutkan dengan pengkajian gizi termasuk kuesioner penelitian dan recall 24 jam. Berdasarkan hasil pengkajian gizi, kemudian materi disampaikan yaitu diet rendah garam III atau diet DASH yaitu makanan yang tinggi sayur, buah, kacang-kacangan, dan produk rendah lemak sesuai diet yang terpilih. Materi konseling gizi yang disampaikan menggunakan brosur diet RG dari RSCM serta diet DASH dari Puslitbang Gizi dengan alat bantu food model. ${ }^{15}$ Hasil konseling gizi oleh peneliti kemudian didokumentasikan dengan format "Asessment, Diagnosis, Intervention, Monitoring and Evaluation" disingkat ADIME.

Data karakteristik subjek dikumpulkan melalui pengisian kuesioner; data tekanan darah sampel diukur sebelum dan sesudah intervensi menggunakan alat pengukur tekanan darah sfigmomanometer; data asupan natrium, sayur, buah dan kacang-kacangan serta data kepatuhan dikumpulkan menggunakan formulir recall 24 jam dan dietimasikan dalam satuan gram dikumpulkan sebelum dan setelah intervensi.

Data yang diperoleh kemudian diolah dan dianalisis secara statistik, distribusi frekuensi variabel meliputi karakteristik sampel yaitu jenis kelamin, usia, dan kebiasaan merokok, jumlah konsumsi natrium dalam sehari, tekanan darah sistolik dan diastolik, asupan sayur,buah,dan kacang-kacangan dalam sehari. Hasil uji normalitas dengan Kolmogorov-Smirnov $Z$ dilakukan untuk semua data, dengan hasil data 
tekanan darah sistolik, diastolik diawal dan akhir penelitian memiliki distribusi data yang tidak normal demikian juga dengan delta atau jumlah penurunan sistolik dan diastolik serta konsumsi kacang-kacangan. Sehingga dilakukan uji perbedaan menggunakan uji nonparametrik Wilcoxon dan Mann-Whitney. Sedangkan asupan natrium, jumlah dan frekuensi konsumsi sayur, buah memiliki distribusi data yang normal sehingga data diolah dengan uji perbedaan pair $t$ test dan independent $t$ test. Uji statistik juga dilakukan dengan uji linear regresi untuk melihat pengaruh berbagai variabel penelitian secara bersamaan.

\section{HASIL}

Berdasarkan Tabel 1 responden yang merupakan penderita hipertensi berjumlah 69 orang terdiri dari 26 laki laki $(37,7 \%)$ dan 43 perempuan $(62,3 \%)$. Pada kelompok intervensi diet RG sebagian besar responden adalah perempuan $(74,3 \%)$. Secara keseluruhan usia subjek dalam rentang usia 40 - 80 tahun dengan nilai usia minimum adalah 43 tahun dan nilai usia maksimum adalah 76 tahun. Pada diet $\mathrm{RG}$, responden didominasi oleh kelompok usia 40-50 tahun (37,1\%), sedangkan pada intervensi diet DASH, distribusi responden dengan karakteristik usia didominasi pada rentang umur 61-70 tahun (41,2\%). Berdasarkan riwayat kebiasaan merokok, sebagian besar responden yang tidak memilki kebiasaan merokok adalah 52 orang $(75,4 \%)$.

Pada Tabel 1 juga terlihat responden penerima intervensi diet RG maupun diet DASH ditemukan bahwa sebagian besar (>50\%) responden sudah tidak bekerja. Sedangkan pada taraf pendidikan, kelompok diet RG maupun kelompok diet DASH didominasi oleh responden pada taraf pendidikan tamat SMA yaitu 37,1 persen dan 44,1 persen. Penderita hipertensi sebagian besar memiliki status gizi normal yaitu 29 orang dengan presentase 42 persen. Sedangkan lainnya diisi oleh penderita yang memilki status gizi kurus, gemuk dan obesitas secara berturut-turut yaitu 3 orang $(4,3 \%), 19$ orang $(27,5 \%)$, dan 18 orang $(26,1 \%)$. Pada diet rendah garam dan diet DASH responden didominasi dengan status gizi gemuk dan obesitas yaitu 54,3 persen dan 52,9 persen.

Penderita hipertensi di kelompok diet DASH lebih banyak tidak disertai penyakit penyerta dari pada kelompok diet RG. Frekuensi penyakit penyerta terbesar hipertensi pada kelompok diet RG adalah tinggi kolesterol $(17,1 \%)$ sedangkan pada kelompok diet DASH, penyakit penyerta hipertensi tertinggi adalah tinggi kolesterol dan Diabetes Mellitus (5,9\%).

\section{Asupan Natrium Sebelum dan Setelah Intervensi}

Pada Tabel 2, nampak rata-rata asupan natrium setelah sekitar 2 minggu diberikan intervensi terjadi penurunan sebanyak 366,34 mg pada kelompok diet RG dan 435,61 mg pada kelompok diet DASH. Berdasarkan uji paired t-test terdapat perbedaan yang bermakna $(p<0,001)$ antara asupan natrium sebelum dan sesudah pemberian intervensi pada kedua kelompok diet.

Selanjutnya, dilakukan uji independent $t$ test didapatkan hasil bahwa tidak terdapat perbedaan yang bermakna antara asupan natrium sebelum $(p=0.117)$ dan setelah $(p=0.457)$ intervensi diantara kelompok yang diberi diet $R G$ dan kelompok yang diberi diet DASH.

Analisa data lanjutan mengenai kepatuhan diet berdasarkan batas konsumsi natrium pada masing -masing diet menunjukkan 28 orang (80\%) pada diet RG dapat melakukan penerapan diet (asupan natrium < $1200 \mathrm{mg}$ ) sedangkan 7 orang $(20 \%)$ lainnya masing memiliki nilai asupan natrium diatas $1200 \mathrm{mg}$. Setelah penerapan diet DASH, sekitar 32 orang $(94,1 \%)$ dapat menerapkan diet DASH sedangkan 2 lainnya $(5,9 \%)$ belum dapat menerapkan.

\section{Tekanan Darah Sebelum dan Setelah Intervensi}

Pada Tabel 3 tekanan darah sistolik sebelum diberikan intervensi diet RG dan DASH pada masing masing kelompok adalah 153,49 mmHg dan 157,26 mmHg. Sedangkan tekanan diastolik ada pada $88,66 \mathrm{mmHg}$ dan 88,44 $\mathrm{mmHg}$. Setelah intervensi diet dberikan, ratarata sistolik-diastolik pada diet RG menjadi 135,63 / 82,06 mmHg. Untuk rata-rata sistolikdiastolik diet DASH diperoleh rata-rata tekanan darah 133,09/77,94 mmHg. Pada kedua intervensi diet tersebut terlihat penurunan nilai tekanan darah baik dari hasil sistolik dan diastolik. Pada hasil uji wilcoxon, disimpulkan bahwa ada perbedaan yang bermakna pada tekanan darah responden antara sebelum 
dengan sesudah diberikan diet DASH maupun $\operatorname{diet} R G(p<0,05)$.

Dengan uji perbedaan mann-whitney pada kelompok diet RG dan diet DASH disimpulkan bahwa tidak ada perbedaan yang bermakna pada kelompok diet RG dan diet DASH pada tekanan darah sistolik sebelum maupun setelah intervensi diberikan $(p>0,05)$. Sedangkan ada perbedaan yang bermakna $(p=0,029)$ pada tekanan diastolik antara kelompok diet DASH dibandingkan kelompok diet RG setelah diberi intervensi (Tabel 3).

Jumlah rata-rata penurunan sistolik dan diastolik pada reponden yang diberikan diet RG berturut-turut adalah $18,4 \mathrm{mmHg}$ dan 7,23 $\mathrm{mmHg}$. Berdasarkan distribusi data responden, 4 orang $(11,5 \%)$ memiliki penurunan tekanan darah sistol di bawah $2 \mathrm{mmHg}$. Sedangkan responden yang memiliki penurunan tekanan diastolik dibawah $2 \mathrm{mmHg}$ hampir separuh dari jumlah responden yaitu sebanyak 17 orang $(48,6 \%)$. Pada penerapan diet DASH yang diberikan pada 34 responden, terjadi rata-rata penurunan sistolik dan diastolik berturut-turut sejumlah 25,06 dan 11,0 mmHg. Berdasarkan distribusi data responden, 3 orang $(8,8 \%)$ memiliki penurunan tekanan darah sistolik di bawah $8 \mathrm{mmHg}$. Sedangkan responden yang memiliki penurunan tekanan diastolik di bawah $8 \mathrm{mmHg}$ sebanyak 13 orang $(38,2 \%)$. Hasil uji Mann-Whitney pada perbandingan delta penurunan sistolik dan diastolik pada diet RG dan diet DASH menunjukkan hasil yang bermakna berturut-turut $p=0,010$ dan $p=0,039$.

Tabel 1

Distribusi Responden Berdasarkan Karakteristik dan Diet

\begin{tabular}{|c|c|c|c|c|c|c|}
\hline \multirow{2}{*}{ Karakteristik } & \multicolumn{2}{|c|}{ Diet RG } & \multicolumn{2}{|c|}{ Diet DASH } & \multicolumn{2}{|c|}{ Total } \\
\hline & $n$ & $\%$ & $\mathrm{n}$ & $\%$ & $\mathrm{n}$ & $\%$ \\
\hline \multicolumn{7}{|l|}{ Jenis kelamin } \\
\hline - Laki-laki & 9 & 25,7 & 17 & 50 & 26 & 37,7 \\
\hline - Perempuan & 26 & 74,3 & 17 & 50 & 43 & 62,3 \\
\hline \multicolumn{7}{|l|}{ Usia } \\
\hline - $\quad 40-50$ tahun & 13 & 37,1 & 2 & 5,9 & 15 & 21,7 \\
\hline - $\quad 51-60$ tahun & 10 & 28,6 & 12 & 35,3 & 22 & 31,9 \\
\hline - $\quad 61-70$ tahun & 9 & 25,7 & 14 & 41,2 & 23 & 33,3 \\
\hline - $>70$ tahun & 3 & 8,6 & 6 & 17,6 & 9 & 13 \\
\hline \multicolumn{7}{|l|}{ Kebiasaan merokok } \\
\hline - Merokok & 8 & 22,9 & 9 & 26,5 & 17 & 24,6 \\
\hline - Tidak merokok & 27 & 77,1 & 25 & 73,5 & 52 & 75,4 \\
\hline \multicolumn{7}{|l|}{ Jenis Pekerjaan } \\
\hline - Tidak bekerja & 24 & 68,6 & 22 & 64,7 & 46 & 66,7 \\
\hline - Bekerja & 11 & 31,4 & 12 & 35,3 & 23 & 33,3 \\
\hline \multicolumn{7}{|l|}{ Pendidikan } \\
\hline - Tidak sekolah & 1 & 2,9 & 0 & 0 & 1 & 1,4 \\
\hline - Tamat SD & 7 & 20,0 & 12 & 35,3 & 19 & 27,5 \\
\hline _ $\quad$ Tamat SMP & 10 & 28,6 & 6 & 17,6 & 16 & 23,2 \\
\hline _ $\quad$ Tamat SMA & 13 & 37,1 & 15 & 44,1 & 28 & 40,6 \\
\hline - Tamat perguruan tinggi & 4 & 11,3 & 1 & 2,9 & 5 & 7,3 \\
\hline \multicolumn{7}{|l|}{ Status Gizi } \\
\hline - Kurus & 1 & 2,9 & 2 & 5,9 & 3 & 4,3 \\
\hline - Normal & 15 & 42,9 & 14 & 41,2 & 29 & 42 \\
\hline - Gemuk & 11 & 31,4 & 8 & 23,5 & 19 & 27,5 \\
\hline - Obesitas & 8 & 22,9 & 10 & 29,4 & 18 & 26,1 \\
\hline \multicolumn{7}{|l|}{ Penyakit Penyerta } \\
\hline - Tanpa penyakit penyerta & 22 & 62,9 & 29 & 85,3 & 51 & 73,9 \\
\hline _ Diabetes Mellitus & 3 & 8,6 & 2 & 5,9 & 5 & 7,2 \\
\hline _ Tinggi Kolesterol & 6 & 17,1 & 2 & 5,9 & 8 & 11,6 \\
\hline - Gout & 1 & 2,9 & 1 & 2,9 & 2 & 2,9 \\
\hline - Komplikasi & 2 & 5,8 & 0 & 0 & 2 & 2,8 \\
\hline - Lainnya & 1 & 2,9 & 0 & 0 & 1 & 1,4 \\
\hline
\end{tabular}


Tabel 2

Perbandingan Asupan Natrium Antara Sebelum dan Sesudah Intervensi Diet RG dan Diet DASH

\begin{tabular}{lcccc}
\hline Asupan & Mean & Minimal & Maksimal & p value) \\
\hline Diet RG & & & & \\
Sebelum Intervensi & $1213,34 \mathrm{mg}$ & $500 \mathrm{mg}$ & $2328,16 \mathrm{mg}$ & $<0,001$ \\
Setelah intervensi & $847 \mathrm{mg}$ & $231,06 \mathrm{mg}$ & $1433,46 \mathrm{mg}$ & \\
Diet DASH & & & & \\
Sebelum Intervensi & $1405,61 \mathrm{mg}$ & $471,4 \mathrm{mg}$ & $2413,36 \mathrm{mg}$ & $<0,001$ \\
Setelah intervensi & $970 \mathrm{mg}$ & $226,48 \mathrm{mg}$ & $2267,33 \mathrm{mg}$ & \\
\hline
\end{tabular}

Tabel 3

Perbandingan Tekanan Darah Sistolik dan Diastolik Sebelum dan Sesudah Intervensi Diet RG dan Diet DASH

\begin{tabular}{lcccc}
\hline Tekanan darah & $\begin{array}{c}\text { Mean } \\
(\mathrm{mmHg})\end{array}$ & $\begin{array}{c}\text { Minimal } \\
(\mathrm{mmHg})\end{array}$ & $\begin{array}{c}\text { Maksimal } \\
(\mathrm{mmHg})\end{array}$ & p value $)$ \\
\hline Tekanan darah sistolik & 153,49 & 100 & 220 & $<0.001$ \\
- Sebelum diet RG & 135,63 & 100 & 190 & \\
- Setelah diet RG & & & & \\
Tekanan darah diastolik & 88,66 & 70 & 120 & $<0,001$ \\
- Sebelum diet RG & 82,06 & 59 & 120 & \\
- Setelah diet RG & & & & \\
Tekanan darah sistolik & 157,26 & 200 & 128 & $<0.001$ \\
- Sebelum diet DASH & 133,09 & 160 & 90 & \\
- Setelah diet DASH & & & & \\
Tekanan darah diastolik & & 110 & 61 & $<0,001$ \\
- Sebelum diet DASH & 88,44 & 90 & 68 & \\
- Setelah diet DASH & 77,94 & 90 & &
\end{tabular}

Tabel 4

Hubungan antara Pemberian Diet RG dan Diet DASH, IMT serta Faktor-Faktor yang Terkait dengan Jumlah Penurunan Tekanan Darah Diastolik

\begin{tabular}{|c|c|c|}
\hline Variabel & Coefficient $(95 \% \mathrm{Cl})$ & $p$ \\
\hline $\begin{aligned} & \text { Pemberian Diet } \\
&- \text { Diet RG } \\
&- \text { Diet DASH }\end{aligned}$ & $\begin{array}{c}\operatorname{Ref} \\
2,072(-1,637 ; 5,781)\end{array}$ & 0,268 \\
\hline IMT $\left(\mathrm{kg} / \mathrm{m}^{2}\right)$ & $-0,420(-0,834 ;-0,006)$ & $0,047^{* *}$ \\
\hline Usia (tahun) & $-0,087(-0,296 ; 0,122)$ & 0,410 \\
\hline $\begin{array}{l}\text { Jenis Kelamin } \\
\begin{aligned}- & \text { Laki-laki } \\
- & \text { Perempuan }\end{aligned}\end{array}$ & $\begin{array}{c}\text { Ref } \\
1,121(-2,789 ; 5,030)\end{array}$ & 0,569 \\
\hline $\begin{array}{l}\text { Tekanan Darah Diastolik Awal } \\
(\mathrm{mmHg})\end{array}$ & $0,343(0,180 ; 0,505)$ & $<0,001^{*}$ \\
\hline
\end{tabular}


Uji linear regresi menunjukkan hasil setelah disesuaikan dengan variabel usia, jenis kelamin, diastolik awal dan IMT maka diet yang diberikan baik diet DASH maupun diet RG tidak ada pengaruhnya terhadap penurunan tekanan darah diastolik. Jumlah penurunan tekanan darah diastolik secara signifikan dipengaruhi oleh tekanan darah diastolik awal $(p<0.001)$ dan IMT $(p=0.047)$. $R$ kuadrat 0,282 berarti semua variabel independen memberi konstribusi 28,2 persen terhadap prediksi jumlah penurunan tekanan darah diastolik (Tabel 4).

\section{Porsi Buah dan Sayur}

Rata-rata porsi sayur yang dapat dikonsumsi sebelum diberikan intervensi dalam sehari adalah 1,3 porsi dengan rata-rata jumlah porsi sayur sebesar 137,8 gram. Setelah diberikan intervensi diet DASH rata-rata konsumsi sayur sehari meningkat menjadi 2,3 porsi dengan jumlah sayur 229,5 gram perharinya. Jenis sayur yang sering dikonsumsi adalah kacang panjang, tauge, sop, bayam, timun, dan tomat. Nampak terlihat adanya peningkatan asupan sayur secara porsi dan

jenis pada akhir intervensi diet DASH. Namun demikian, rata- rata porsi asupan sayur sehari sehari responden kelompok DASH belum sesuai dengan perencanaan menu makanan.

Sedangkan pada intervensi buah, rata rata porsi buah yang dapat dikonsumsi sebelum diberikan intervensi selama sehari adalah 1,15 porsi dengan rata-rata jumlah porsi buah sebesar 107,9 gram. Setelah diberikan intervensi diet DASH rata-rata konsumsi buah sehari meningkat menjadi 2,25 porsi dengan jumlah buah 226,76 gram perharinya. Seperti halnya asupan sayur, peningkatan asupan buah rata-rata responden diet DASH belum mencapai perencanaan menu diet DASH (5-6 porsi). Jenis buah yang sering dikonsumsi adalah pisang, jeruk, papaya, melon, serta buah naga.

Berdasarkan Tabel 5 hasil uji independent Sample t-test ditemukan bahwa adanya perbedaan yang bermakna pada porsi sayur awal dan akhir, porsi buah awal dan akhir, jumlah porsi sayur awal dan akhir, serta jumlah porsi buah awal dan akhir diantara kelompok yang diberi diet $R G$ dan diet DASH ( $p<0,05$ dan $p<0,001)$.

Tabel 5

Perbandingan Porsi Asupan Sayur dan Buah pada Diet RG dengan Diet DASH

\begin{tabular}{lccc}
\hline Asupan sayur dan buah & Diet RG & Diet DASH & $p$ value \\
\hline Asupan sayur & 0,68 & 1,3 & 0,001 \\
- Porsi sayur awal & 1,6 & 2,3 & 0,002 \\
- Porsi sayur akhir & 69,3 & 137,8 & 0,001 \\
- Jumlah porsi sayur awal & 147 & 229,5 & 0,001 \\
- Jumlah porsi sayur akhir & & & \\
Asupan buah & 0,63 & 1,15 & 0,015 \\
- Porsi buah awal & 1,3 & 2,25 & $<0,001$ \\
- Porsi buah akhir & 55,3 & 107,9 & 0,017 \\
- Jumlah porsi buah awal & 128,4 & 226,76 & $<0,001$ \\
\hline - Jumlah porsi buah akhir & & &
\end{tabular}

Tabel 6

Perbandingan Rata- Rata Porsi Asupan Kacang -Kacangan pada Diet RG dengan Diet DASH per hari

\begin{tabular}{lccc}
\hline Asupan kacang-kacangan & Diet RG & Diet DASH & p value) \\
\hline Porsi kacang-kacangan awal & 0,9 & 1 & 0,683 \\
Porsi kacang-kacangan akhir & 1,2 & 1,5 & 0,384 \\
Jumlah asupan kacang -kacangan awal & $50,2 \mathrm{~g}$ & $62,9 \mathrm{~g}$ & 0,259 \\
Jumlah asupan kacang-kacangan akhir & $74,6 \mathrm{~g}$ & $86,5 \mathrm{~g}$ & 0,354 \\
\hline
\end{tabular}




\section{Porsi Kacang-Kacangan}

Rata -rata asupan kacang- kacangan per hari kelompok diet RG sebelum diberikan intervensi 50,2 gram dan meningkat menjadi 74,6 gram dengan nilai uji Wilcoxon $p<0,001$, sedangkan pada kelompok intervensi diet DASH asupan kacang-kacangan meningkat dari 62,9 gram menjadi 86,5 gram dengan nilai $p=$ 0,041 . Maka terjadi perbedaan yang bermakna pada asupan kacang -kacangan antara sebelum dan sesudah diberikan intervensi pada kedua kelompok $(p<0,05)$.

Berdasarkan Tabel 6, hasil uji MannWhitney ditemukan bahwa tidak adanya perbedaan yang bermakna pada porsi atau jumlah kacang-kacangan baik pada awal atau akhir intervensi diantara kelompok yang diberi $\operatorname{diet} R G$ dan diet DASH $(p>0,05)$.

\section{BAHASAN}

Keterbatasan penelitian ini, intervensi diet diberikan dalam bentuk konseling gizi, tidak memberikan anjuran diet dalam bentuk makanan yang terkontrol sehingga ada kemungkinan bias. Namun demikian, konseling gizi memiliki kelebihan yaitu memberikan kebebasan kepada responden untuk mengimplementasikan dietnya. Siervo (2015) dalam meta analisisnya juga menunjukkan hampir separuh intervensi penelitian dilakukan dengan konseling gizi. ${ }^{16}$

Setelah dilakukan 2 minggu intervensi diet DASH dan diet RG terlihat penurunan nilai tekanan darah baik sistolik dan diastolik. Hasil penelitian ini sesuai dengan penelitian yang dilakukan Dewifianita R (2017) menunjukkan bahwa terdapat perbedaan tekanan diastolik sebelum dan sesudah diberikan konseling diet DASH $(p=0,0104)$ dan menunjukkan ada hubungan pemberian konseling diet DASH terhadap perubahan tekanan darah. ${ }^{10}$ Penelitian Juraschek (2017) menyatakan bahwa diet Dash selama satu minggu efektif menurunkan tekanan darah dibandingkan diet rendah garam selama 4 minggu. ${ }^{17}$ Penelitian Uliatiningsih (2019) menunjukkan ada perubahan yang signifikan antara tekanan darah sistolik dan diastolik sebelum dan setelah intervensi $(p=0,000) .{ }^{11}$ Lebih lanjut, penelitian yang dilakukan oleh Rista juga menunjukkan adanya hubungan yang signifikan antara penerapan metode DASH dengan tingkat hipertensi pada lansia. ${ }^{18}$
Uji Mann Whitney menunjukkan adanya pengaruh diet DASH hanya terhadap penurunan tekanan darah diastolik dibandingkan diet RG. Hal ini mungkin terjadi karena perbedaan asupan natrium yang tidak signifikan dan karakteristik responden yang berbeda pada kedua kelompok intervensi. Namun berdasarkan delta penurunan tekanan darah, penelitian ini menunjukkan penurunan tekanan darah sistolik dan diastolik pada diet DASH berbeda bermakna dengan diet RG. Hal ini sejalan dengan penelitian Epstein (2012) dan Juraschek (2017) yang menunjukkan ada pengaruh diet DASH terhadap penurunan tekanan darah pasien hipertensi. ${ }^{19,20}$

Berbeda dengan keempat penelitian tersebut, penelitian Nadya Shafa (2014) menunjukkan bahwa tidak ada perbedaan tekanan darah sistolik dan diastolik sebelum dan setelah intervensi diet DASH selama 14 hari. Ada beberapa kemungkinan terjadinya perbedaan hasil antara lain status gizi, tingkatan hipertensi, usia responden maupun jumlah sampel. ${ }^{12}$

Jumlah rata-rata penurunan sistolik dan diastolik pada reponden yang diberikan diet RG berturut-turut adalah $18,4 \mathrm{mmHg}$ dan 7,23 $\mathrm{mmHg}$. Menurut tabel modifikasi gaya hidup dalam mengatur tekanan darah tinggi pada jurnal JNC VII bahwa paparan intervensi diet rendah garam (natrium) dapat menyumbangkan rata-rata penurunan tekanan darah $2-8$ $\mathrm{mmHg} .{ }^{9}$ Pada tekanan sistolik maupun diastolik, penurunan tekanan darah yang dihasilkan melebihi literatur tersebut. Hal ini terjadi karena responden mengonsumsi obat antihipertensi (captopril) sehingga membantu penurunan nilai tekanan darah lebih banyak. ${ }^{21}$ Berdasarkan distribusi data responden, 4 orang $(11,5 \%)$ memiliki penurunan tekanan darah sistolik di bawah $2 \mathrm{mmHg}$. Sedangkan responden yang memiliki penurunan tekanan diastolik dibawah 2 $\mathrm{mmHg}$ hampir separuh dari jumlah responden yaitu sebanyak 17 orang $(48,6 \%)$.

Lebih besarnya penurunan tekanan darah sistolik $(25,06 \mathrm{mmHg})$ dan diastolik $(11 \mathrm{mmHg})$ pada diet DASH dibanding diet RG kemungkinan karena pada intervensi diet DASH juga mengonsumsi susunan makanan dengan kaya buah, sayur yang secara teori dapat menyumbangkan rata-rata penurunan tekanan darah sistolik 8 - 14 mmHg., ${ }^{9,22}$ Namun demikian hasil uji statistik menunjukkan bahwa 
perbedaan konsumsi sayur dan buah yang signifikan antara pasien yang diberi diet DASH dan diet RG telah berlangsung sejak awal intervensi. Hal ini menunjukkan meningkatnya konsumsi sayur dan buah kemungkinan tidak hanya akibat intervensi diet DASH namun ada faktor lain yang mempengaruhinya. Penelitian lain yang dilakukan oleh Siervo yang dilakukan dengan atau tanpa penyakit komorbid menunjukkan ada pengaruh diet DASH terhadap penurunan sistolik dan diastolik. ${ }^{16}$

Penelitian ini juga menunjukkan hasil bahwa terdapat penurunan bermakna asupan natrium pada kelompok diet rendah garam dan diet DASH sesudah intervensi. Namun asupan natrium tidak berbeda bermakna diantara kedua kelompok. Dibandingkan dengan diet RG, penurunan rata-rata asupan natrium sesudah intervensi dilakukan lebih besar terjadi pada kelompok diet DASH. Hal ini sesuai dengan penelitian Epstein et.al (2012) yang menunjukkan adanya penurunan asupan natrium setelah melakukan diet DASH. ${ }^{19}$ Sama halnya pada penelitian Juraschek (2017) menunjukkan kombinasi diet rendah garam dan diet DASH mampu menurunkan tekanan darah yang lebih besar dibandingnkan dengan pasienyang hanya mendapatkan diet rendah garam saja. ${ }^{23}$

Berdasarkan data diatas, nampak bahwa lebih banyak responden yang dapat menerapkan diet DASH dibandingkan diet rendah garam kemungkinan dikarenakan toleransi natrium pada diet DASH lebih rendah yaitu $1500 \mathrm{mg}$ dibandingkan diet RG yang memiliki batas $1200 \mathrm{mg}$. Namun demikian asupan natrium maksimal setelah intervensi masih ada yang melampaui ambang kecukupan natrium diet RG $(>1200 \mathrm{mg})$ dan diet DASH (>1500mg) menunjukkan beberapa responden belum mematuhi anjuran diet yang diberikan ${ }^{8}$.

Disamping menurunnya asupan natrium, diet DASH menekankan mengonsumsi sayuran dan buah dimana keduanya merupakan bahan makanan yang rendah natrium. Walaupun uji statistik menunjukkan adanya perbedaan porsi atau jumlah sayuran dan buah yang bermakna sejak awal penelitian namun di akhir penelitian juga menunjukkan rata-rata porsi atau jumlah konsumsi sayuran dan buah lebih banyak bermakna pada diet DASH dibandingkan diet RG. ${ }^{24}$ Temuan meningkatnya konsumsi sayuran dan buah pada diet DASH juga ditemukan pada penelitian Epstein et al (2012). ${ }^{19}$

Lebih lanjut hasil analisa dengan linear regresi menunjukkan tekanan darah diastolik awal dan IMT berpengaruh secara signifikan terhadap jumlah penurunan tekanan darah diastolik pada akhir penelitian, jenis diet RG maupun diet DASH tidak menunjukkan hasil yang bermakna. Penerapan diet DASH yang kaya konsumsi sayur dan buah mungkin mempengaruhi penurunan $\mathrm{BB}$ yang pada akhirnya dapat menurunkan tekanan darah. ${ }^{25}$ Karakteristik responden yang diberi diet DASH dan diet RG lebih dari 50\% memiliki status gizi gemuk dan obes. Penelitian Harahap (2009) juga menunjukkan diet DASH tidak hanya menurunkan tekanan darah namun juga menurunkan BB. ${ }^{26}$

Saat ini penerapan diet DASH yang terdapat di puskesmas atau rumah sakit masih belum banyak, dikarenakan diet DASH masih belum dikenal dibandingkan diet RG yang sejak dulu diterapkan di Puskesmas maupun Rumah Sakit. Penelitian ini diharapkan dapat berkontribusi terhadap peningkatan pengetahuan ahli gizi terkait efektivitas diet DASH dibandingkan diet RG bagi pasien dengan atau tanpa penyakit komorbid. Pada tahun 2019, Persatuan Ahli Gizi Indonesia (PERSAGI) dan Asosiasi Dietisien Indonesia (ASDI) telah menerbitkan penuntun diet dan terapi gizi yang memuat diet DASH. Penelitian lebih lanjut diharapkan dapat dilakukan untuk mempelajari penggunaan diet DASH dalam menurunkan tekanan darah tinggi pada pasien di RS.

\section{SIMPULAN DAN SARAN}

\section{Simpulan}

Ada hubungan antara pemberian diet DASH melalui konseling gizi terhadap penurunan tekanan darah sistolik dan diastolik serta asupan natrium pasien hipertensi yang bermakna dibandingkan diet RG. Namun setelah disesuaikan dengan berbagai variabel, maka tekanan darah diastolik awal dan IMT yang mempengaruhi jumlah penurunan tekanan darah diastolik responden. 


\section{Saran}

Selain diet RG maka diet DASH dapat direkomendasikan untuk membantu menurunkan tekanan darah pada pasien hipertensi.

\section{UCAPAN TERIMA KASIH}

Ucapan terima kasih ditujukan kepada Direktur Poltekkes Kemenkes Jakarta II, pimpinan, tenaga kesehatan dan ahli gizi Puskesmas Larangan Utara serta semua pihak yang telah membantu terlaksananya penelitian ini. Terima kasih kepada Saudara Dzakiyatul Itsna dan Indah Ratnasari yang telah membantu mempersiapkan manuskrip ini.

\section{RUJUKAN}

1. Rudianto BF. Menaklukan Hipertensi dan Diabetes. Sakkhasukma, editor. Yogyakarta; 2013.

2. Kemenkes RI. Infodatin stroke. Jakarta Selatan; 2019.

3. Kemenkes RI. Riset Kesehatan Dasar 2018. In Jakarta: Departemen Kesehatan, Republik Indonesia; 2018.

4. Kementrian Kesehatan RI. Infodatin Hipertensi. 2014;

5. Almatsier S. Penuntun Diet edisi Baru, Instalasi Gizi Perjan RS Ciptomangunkusumo dan Asosiasi Dietisien Indonesia. 2013.

6. Setiyani E. Perbedaan Asupan Natrium (Na), Kalium (K) Sebelum dan Sesudah Edukasi Pada Pasien Hipertensi Rawat Jalan di Puskesmas Wonokerto II Kabupaten Pekalongan Jawa Tengah [Internet]. Bachelor thesis, Universitas Muhammadiyah Semarang; 2018. Available from:

http://repository.unimus.ac.id/2051/8/MANU SCRIPT.pdf

7. Damayanti D, Pritasari P, Prayitno N, Ngadiarti I, Zulfianto $\mathrm{N}$ aria. Comparing The Effect Between Energy Reducing Diet abd Food Combining on Body Weight Change Among Overweight Adult. SANITAS J
Teknol dan Seni Kesehat. 2020;11(1):1-13.

8. Kresnawan T. Asuhan Gizi Pada Hipertensi. Gizi Indones. 2014;34(2):143-7.

9. Schwartz GL, Sheps SG. A review of the Sixth Report of the Joint National Committee on Prevention, Detection, Evaluation, and Treatment of High Blood Pressure. Curr Opin Cardiol. 1999;14(2):161-8.

10. Dewifianita R. Pengaruh Pemberian Konseling Diet Dash (Dietary Approach To Stop Hypertension) Terhadap Perubahan Tekanan Darah Pada Penderita Hipertensi Peserta Prolanis Di Puskesmas Sentolo I [Internet]. Bachelor thesis, Poltekkes Kemenkes Yogyakarta; 2017. Available from:

http://eprints.poltekkesjogja.ac.id/240/1/31R IZKY DEWIFIANITA.pdf

11. Uliatiningsih R. Pengaruh Edukasi Diet Dash (Dietary Approaches To Stop Hypertension)Terhadap Kepatuhan Diet Dan Tekanan Darah Pada Penderita Hipertensi Rawat Jalan Di Rumkital Marinir Cilandak [Internet]. Bachelor thesis, Universitas Binawan; 2020. Available from: http://repository.binawan.ac.id/59/

12. Nurhumaira NS, Rahayuningsih HM. Journal of Nutrition College, Volume 3 , Nomor 4 , Tahun 2014 , Halaman 554-564 Journal of Nutrition College, Volume 3 , Nomor 4, Tahun 2014 Online di: http://ejournal-s1.undip.ac.id/index.php/jnc Journal of Nutrition College, Volume 3 , Nomor 4 , Ta. J Nutr Coll [Internet]. 2014;3(4):554-64. Available from: https://ejournal3.undip.ac.id/index.php/jnc/a rticle/view/6850/6577

13. Notoatmodjo S. Metodologi Penelitian Kesehatan. Jakarta: Rineke Cipta; 2010.

14. Puskesmas Larangan Utara. Laporan Tahunan Puskesmas Larangan Utara. Tangerang; 2016.

15. Instalasi Gizi. Daftar Diet Rendah Garam. Jakarta: RSUPN Dr. Cipto Mangunkusumo; 2015.

16. Siervo M, Lara J, Chowdhury S, Ashor A, Oggioni C, Mathers JC. Effects of the dietary approach to stop hypertension 
(DASH) diet on cardiovascular risk factors: A systematic review and meta-analysis. $\mathrm{Br}$ J Nutr. 2015;113(1):1-15.

17. Juraschek SP, Woodward M, Sacks FM, Carey VJ, Miller ER, Appel LJ. Time Course of Change in Blood Pressure from Sodium Reduction and the DASH Diet. Hypertension. 2018;70(5):923-9.

18. Apriana R, Rohana N, Simorangkir $\mathrm{Y}$. Hubungan Penerapan Metode DASH (Dietary Approach to Stop Hypertension) dengan Tngkat Hipertensi. Medisains. 2017;15(3):179-84.

19. Blumenthal JA, Epstein DE, Sherwood A, Smith PJ, Craighead L, Caccia C, et al. Determinants and Consequences of Adherence to the Dietary Approaches to Stop Hypertension Diet in African-American and White Adults with High Blood Pressure: Results from the ENCORE Trial. J Acad Nutr Diet. 2012;112(11):1763-73.

20. Quispe-Tintaya W. Time Course of Change in Blood Pressure from Sodium Reduction and the DASH Diet, Hypertension. Physiol Behav. 2017;176(3):139-48.

21. Maris SA, Williams JS, Sun B, Brown $S$, Mitchell GF, Conlin PR. Interactions of the DASH Diet with the Renin-Angiotensin-
Aldosterone System. Nutr Heal Dis. 2019;3:1-7.

22. Padma V. DASH Diet in Preventing Hypertension. Adv Biol Res (Rennes). 2014;8(2):94-6.

23. Juraschek SP, Miller ER, Weaver CM, Appel LJ. Effects of Sodium Reduction and the DASH Diet in Relation to Baseline Blood Pressure. J Am Coll Cardiol. 2018;70(23):2841-8.

24. Padma V. DASH Diet in Preventing Hypertension DASH Diet in Preventing Hypertension. Adv Biol Res. 2015;8(2):2-5.

25. Epstein DE, Sherwood A, Smith PJ, Craighead L, Caccia C, Lin $P$, et al. Determinants and Consequences of Adherence to the DASH Diet in African American and White Adults with High Blood Pressure: Results from the ENCORE Trial. J Acad Nutr Diet. 2013;112(11):1763-73.

26. Harahap H, Hardinsyah, Setiawan B, Effendi I. Pengaruh Diet Penurunan Berat Badan dan Tekanan Darah Pada Penderita Prahipertensi yang Kegemukan [Internet]. Doctoral Disertation, Institut Pertaninan Bogor; 2009. Available from: https://repository.ipb.ac.id/handle/12345678 9/22458 
